\title{
TKTLI is overexpressed in a large portion of non-small cell lung
} cancer specimens

\author{
Holger Schultz ${ }^{\dagger 1}$, Daniel Kähler ${ }^{\dagger 1}$, Detlev Branscheid ${ }^{2}$, Ekkehard Vollmer ${ }^{1}$, \\ Peter Zabel ${ }^{3,4}$ and Torsten Goldmann*1
}

Address: ${ }^{1}$ Research Center Borstel, Clinical and Experimental Pathology, Parkallee 3a, D-23845, Borstel, Germany, ${ }^{2}$ Hospital Großhansdorf, Department of Thoracic Surgery, Wöhrendamm 80, D-22927, Großhansdorf, Germany, ${ }^{3}$ Medical University Hospital III Lübeck/Department of

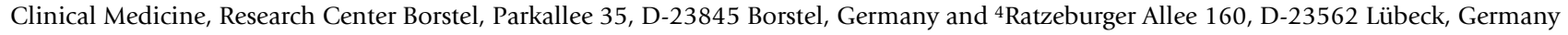

Email: Holger Schultz - hschultz@fz-borstel.de; Daniel Kähler - dkaehler@fz-borstel.de; Detlev Branscheid - d.branscheid@kh-grosshansdorf.de; Ekkehard Vollmer - evollmer@fz-borstel.de; Peter Zabel - pzabel@fz-borstel.de; Torsten Goldmann* - tgoldmann@fz-borstel.de

* Corresponding author †Equal contributors

Published: 12 August 2008

Diagnostic Pathology 2008, 3:35 doi:10.1 186/1746-1596-3-35
Received: 29 July 2008

Accepted: 12 August 2008

This article is available from: http://www.diagnosticpathology.org/content/3/I/35

(c) 2008 Schultz et al; licensee BioMed Central Ltd.

This is an Open Access article distributed under the terms of the Creative Commons Attribution License (http://creativecommons.org/licenses/by/2.0), which permits unrestricted use, distribution, and reproduction in any medium, provided the original work is properly cited.

\begin{abstract}
In several tumors the transketolase activity, controlled inter alia by enzymes of the pentose phosphate pathway which is an alternative, energy generating reaction-cascade to glycolysis, has been correlated with proliferation. The increase of thiamine-dependant transketolase enzyme reactions is induced especially through upregulated transketolase-like enzyme I (TKTLI)-activity; that shows TKTLI to be a causative enzyme for tumors enhanced, anaerobic glucose degradation. We investigated TKTLI-expression in 88 human, formalin-fixed non-small cell lung cancer tissues and 24 carcinomas of the breast by immunohistochemical stainings applying a 0 to 3 staining-score system ( 3 = strongest expression). For means of validation we additionally stained 40 NSCLC fixed and paraffin-embedded utilizing the HOPE-technique; showing comparable results to the formalinfixed, paraffin-embedded specimens (not shown). Potential correlations with age, sex, TNMclassification parameters and tumor grading as well as tumor transcription factor I (TTFI) and surfactant protein A (SPA) expression were investigated. $40.9 \%$ of the analyzed lung tumors expressed TKTLI weakly (Score I), 38.6\% moderately (score 2 ) and I7.1\% strongly (score 3 ). 3 tumors were diagnosed TKTLI-negative (3.4\%; score 0$)$. All Breast cancer specimen stainings were positive and scored I: $32 \%$; scored 2: $36 \%$; scored 3: $32 \%$. Alveolar macrophages and Alveolar Epithelial Cells Type II were also found to be TKTLI-positive.
\end{abstract}

None of the listed clinical parameters could be found to show a significant correlation to TKTLI signal appearance.

Although we describe the expression of TKTLI in lung cancers, we need to state that up till now there is no scientific indication for any treatment regimens based upon these findings.

\section{Findings}

The ability of tumors to degrade glucose, even in the presence of oxygen, through the anaerobic transketolasedependant pentose phosphate pathway has recently shown TKTL1 to particularly influence total transketolase activity and cell proliferation [1]. TKTL1 mRNA silencing (via small interfering anti-TKTL1-mRNA constructs) leads to inhibition of cell proliferation in colorectal cancer; pro- 
tein overexpression and a significant correlation to Her2 overexpression was found in breast cancer cells where 89\% expressed TKTL1 and 45\% showed strong expression $[2,3]$. Gastric tumors and granulosa cell tumors of the ovary were also found to express high amounts of TKTL1 (36.9\%; 81\%) [4,5]. Further, with renal cancer another carcinoma displayed intensively elevated transketolase activity due to TKTL1-upregulation [6]. Proliferationinfluencing activities of TKTL1 might play a role in a variety of cancers. Hence we investigated a capacious collective of 88 formalin-fixed non-small cell lung cancer (NSCLC)-tissues (39 adenocarcinomas; 49 squamous cell carcinomas) by immunohistochemistry to describe TKTL1 protein expression in human lung carcinomas. A collective of 24 breast cancer specimens was also included in the study (21 invasive-ductal; 1 tubular; 1 lobular; 1 mucinous carcinoma). Further, we challenged a potential correlation of TKTL1 to age, sex, TNM-classification and grading as well as TTF1 and SPA expression.

After lobectomy or pneumonectomy tumor tissues were immediately fixed with formalin and processed in the following over-night-procedure: formalin $1 \mathrm{~h} 30 \mathrm{~min}$; following an alcohol series (70\% $1 \mathrm{~h} 30 \mathrm{~min} ; 80 \% 1 \mathrm{~h} ; 96 \%$ $1 \mathrm{~h}$ for 2 times; $100 \% 1 \mathrm{~h}$ for 3 times; Histoclear for $1 \mathrm{~h} 2$ times; subsequently paraplast is brought into the tissue at $60^{\circ} \mathrm{C}$ for $1 \mathrm{~h} 30 \mathrm{~min}$; then another $2 \mathrm{~h}$ ). Each step was followed by a $30 \mathrm{~min}$. drop-off delay before the next step was started. After resection breast cancer specimens were processed in the same manner. Additionally we investigated 40 HOPE (Hepes Glutamic Acid Buffer Mediated Organic Solvent Protection Effect)-fixed NSCLC-tissue probes to validate the formalin fixation. After embedding in paraffin the blocks were shelved for 0-6 years within a tissue archive. For increased inter specimen comparability and even staining quality we utilized Tissue Microarrays (TMAs). These TMAs were produced from donor tissue blocks using an MTA1 (Manual Tissue Arrayer 1) device (Alphametrix, Germany), cut and mounted on microscope slides (Super Frost Plus, Langenbrink, Germany). For homogeneous high-throughput staining conditions the tissues were stained automatically (Autostainer 480, Medac, Germany).

The TMAs were deparaffinized and rehydrated by the following series at room temperature: $10 \mathrm{~min}$. xylol incubation; 2 min. absolute alcohol (2 times); 2 min. 96\% alcohol (2 times); 2 min. 90\% alcohol; 2 min. 80\% alcohol; $2 \mathrm{~min}$. 70\% alcohol; $2 \mathrm{~min}$. aqua dest. (2 times). For antigen retrieval $30 \mathrm{~min}$. citrate buffer cooking in was chosen. The primary antibody (anti-TKTL1; clone: JFC12T10; Zytomed Systems, Berlin) was incubated for $30 \mathrm{~min}$. in a 1:100 dilution. We used an enzyme-polymersystem (ZytochemPlus HRP Polymer Kit, Zytomed Systems) for sensitive detection with permanent AEC (Zytomed Sys- tems) as chromogen. Tissue arrays were counterstained by incubation in Mayer's haemalum for 5 minutes. Negativecontrols were included in each staining series under omission of primary antibody.

The immunohistochemical stainings displayed elevated expression of TKTL1 in human lung cancer: 40.9\% expressed TKTL1 weakly (score 1), 38.6\% moderately (score 2), $17.1 \%$ strongly (score 3 ), and $3.4 \%$ of the tumors were TKTL1-negative (score 0; Figure 1). Breast cancer specimen stainings were scored 0 : none; scored 1 : 32\%; scored 2: 36\%; scored 3: 32\% (Figure 2). In general, adenocarcinomas were more often strongly positive (score 3$)$ than the squamous cell carcinomas $(22.1 \%$ for adenocarcinomas and $12.2 \%$ for squamous cell carcinomas). Staining of the HOPE-fixed specimens showed comparable results; these results verify findings in the five cases of adenocarcinomas of the lung described by Langbein et al. [7].

Signals were recognized in the cytoplasm and occasionally in nuclei of tumor cells. There was a conspicuous amount of signal-containing alveolar macrophages and alveolar epithelial cells type II (AEC II cells), observed in the close neighborhood of the NSCLC (Figures 3D and 3E) as well as in completely healthy parts of lung tissue (not shown). Examples of stained tumor types, alveolar macrophages and AEC II cells are shown in figure 3A-E. No staining was found in negative controls. Comparison of TKTL1-expression to several clinical parameters revealed that there is no significant correlation between TKTL1-appearance and age, sex, TNM-classification parameters or tumor grading. Further no correlation could be defined concerning SPA and TTF1 expression.

A high variability of TKTL1-expression has been described in several tumor types. There is proven evidence that TKTL1-associated or -inducing, abnormal glucose degradation is increased in tumors [3-10]. But TKTL1 is also a key enzyme in the healthy organism whose activation-status influences the balance of anaerobic glucose- or oxygen-focussed bioenergy-obtainment. Natural appearance is proven through positive detected macrophages and AEC II cells (Figures 3D and 3E) as well as signals in healthy lung tissues. Therefore tests on cancer cells or cancer tissues alone are not capable to gain insights into the complex situation in patients subjected to diets or other treatments. We have shown that a large portion of NSCLC overexpresses TKTL1; moreover there was a significant expression in non malignant cells of the lungs. Although it is tempting to speculate of a potential therapeutic benefit by modulation of TKTL1-activity in the future, further studies are necessary to investigate the real amount of effects during TKTL1-targeted diets or therapies within the human organism. 


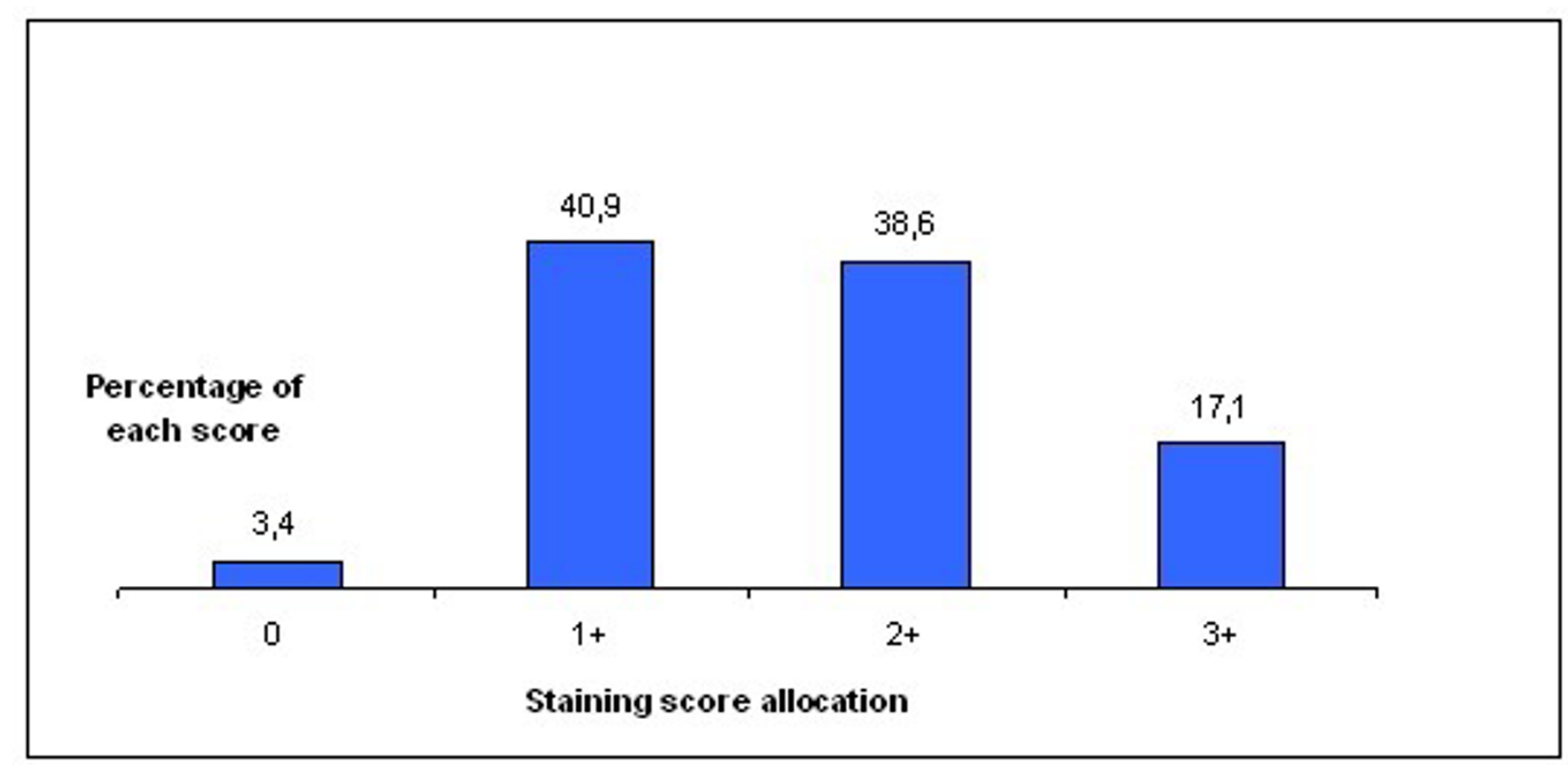

Figure I

Allocation of the stained lung cancer specimens to the four different staining scores.

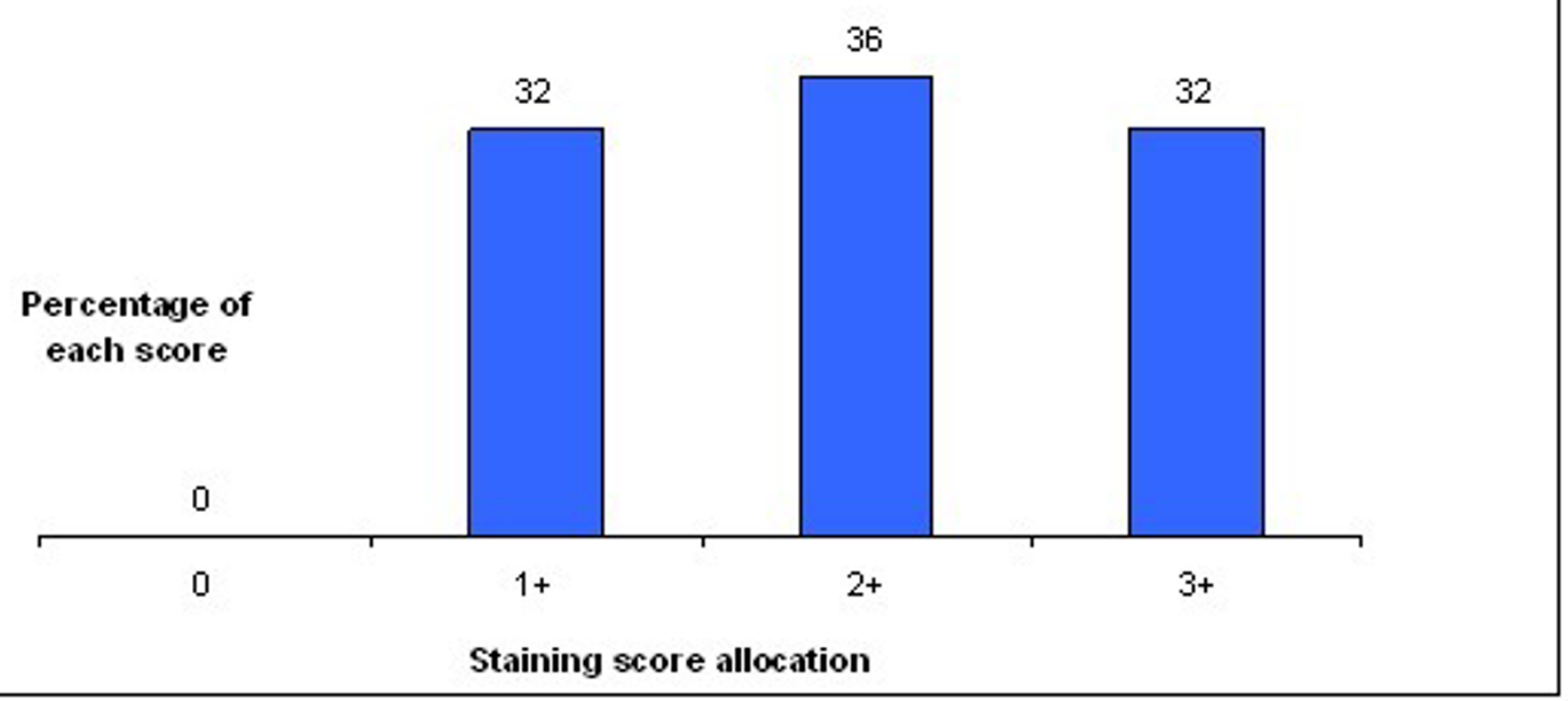

Figure 2

Allocation of the stained breast cancer specimens to the four staining scores. 

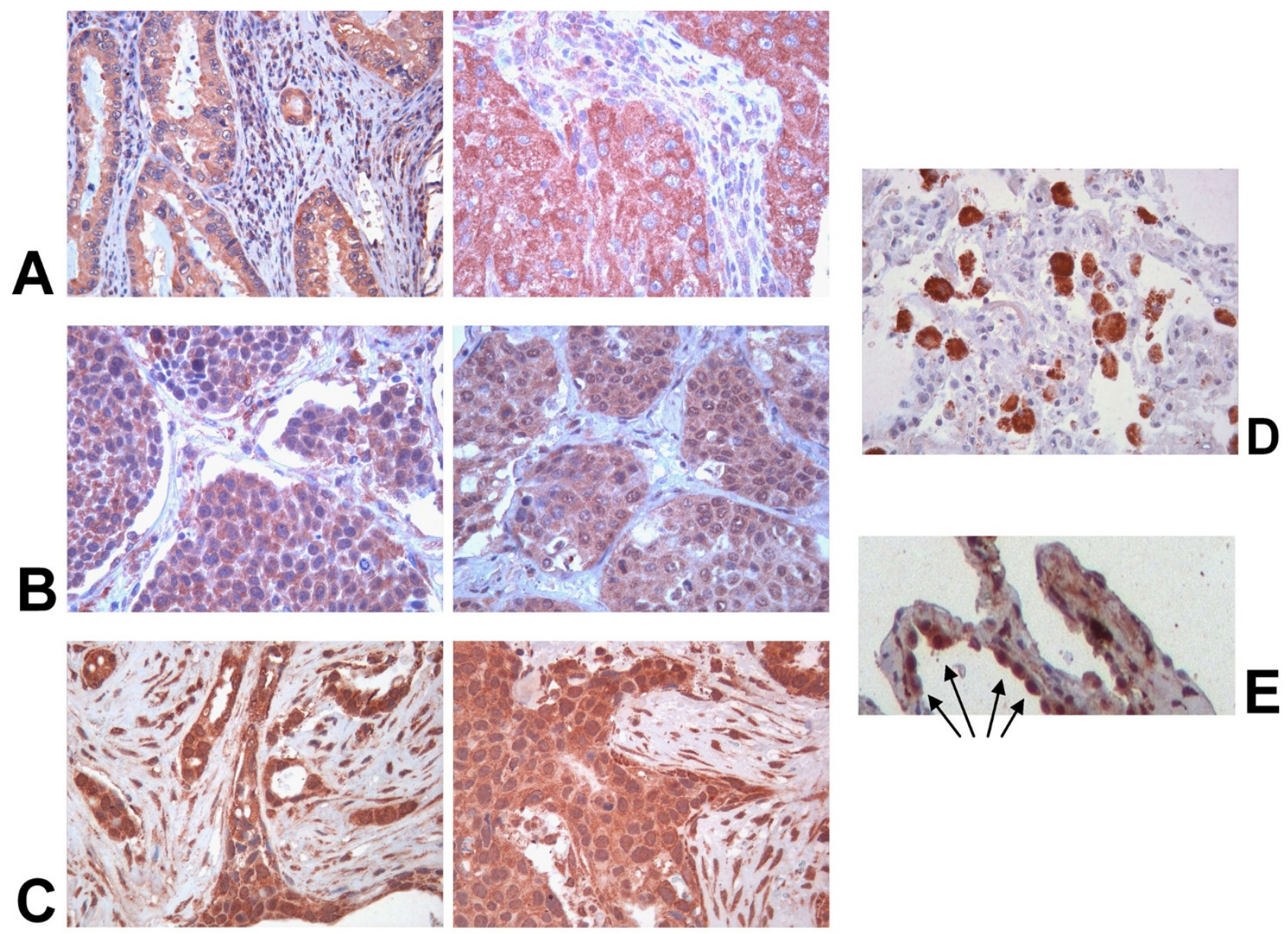

Figure 3

Examples of TKTLI-stained A) adenocarcinomas; B) squamous cell carcinomas; C) breast cancer specimens; D) TKTLI-positive macrophages in the neighbourhood of an adenocarcinoma and E) TKTLI-positive AEC II cells in the neighbourhood of an adenocarcinoma (arrows).

\section{Competing interests}

The authors declare that they have no competing interests.

\section{Authors' contributions}

HS and DK drafted the manuscript and analyzed the sections. DB was responsible for the surgical part and clinical data. EV and PZ were responsible for the histopathological and the pneumological aspects. TG conducted the study together with EV and PZ and was involved in drafting the manuscript. All authors have read and approved the present manuscript.

\section{Acknowledgements}

The authors thank Jasmin Tiebach and Maria Lammers for excellent technical assistance.

\section{References}

I. Hu LH, Yang JH, Zhang DT, Zhang S, Wang L, Cai PC, Zheng JF, Huang JS: The TKTLI gene influences total transketolase activity and cell proliferation in human colon cancer LoVo cells. Anticancer Drugs 2007, 18:427-433.

2. Zhang S, Yang JH, Guo CK, Cai PC: Gene silencing of TKTLI by RNAi inhibits cell proliferation in human hepatoma cells. Cancer Lett 2007, 8: 108-1 I4.

3. Földi M, Stickeler E, Bau L, Kretz O, Watermann D, Gitsch G, Kayser G, Zur Hausen A, Coy JF: Transketolase protein TKTLI overexpression: A potential biomarker and therapeutic target in breast cancer. Oncol Rep 2007, 17:84I-845.

4. Staiger WI, Coy JF, Grobholz R, Hofheinz RD, Lukan N, Post S, Schwarzbach MH, Willeke F: Expression of the mutated transketolase TKTLI, a molecular marker in gastric cancer. Oncol Rep 2007, 16:657-661.

5. Schmidt M, Kammerer U, Segerer S, Cramer A, Kohrenhagen N, Dietl J, Voelker HU: Glucose metabolism and angiogenesis in granulosa cell tumors of the ovary: Activation of Akt, expression of M2PK, TKTLI and VEGF. Eur J Obstet Gynecol Reprod Biol 2008, I39(I):72-78.

6. Langbein S, Frederiks WM, zur Hausen A, Popa J, Lehmann J, Weiss C, Alken P, Coy JF: Metastasis is promoted by a bioenergetic switch: new targets for progressive renal cell cancer. Int $j$ Cancer 2008, I:2422-2428.

7. Langbein S, Zerilli M, Zur Hausen A, Staiger W, Rensch-Boschert K, Lukan N, Popa J, Ternullo MP, Steidler A, Weiss C, Grobholz R, Willeke F, Alken P, Stassi G, Schubert P, Coy JF: Expression of tran- 
sketolase TKTLI predicts colon and urothelial cancer patient survival: Warburg effect reinterpreted. $\mathrm{Br} J$ Cancer 2006, 27:578-585.

8. Zhang S, Yue JX, Yang JH, Cai PC, Kong WJ: Overexpression of transketolase protein TKTLI is associated with occurrence and progression in nasopharyngeal carcinoma: $A$ potential therapeutic target in nasopharyngeal carcinoma. Cancer Biol Ther 2008, 7(4):517-522.

9. Völker HU, Scheich M, Schmausser B, Kämmerer U, Eck M: Overexpression of transketolase TKTLI is associated with shorter survival in laryngeal squamous cell carcinomas. Eur Arch Otorhinolaryngol 2007, 264: |43|-|436.

10. Krockenberger M, Honig A, Rieger L, Coy JF, Sutterlin M, Kapp M, Horn E, Dietl J, Kammerer U: Transketolase-like I expression correlates with subtypes of ovarian cancer and the presence of distant metastases. Int J Gynecol Cancer 2007, I7:101-106.

Publish with Bio Med Central and every scientist can read your work free of charge

"BioMed Central will be the most significant development for disseminating the results of biomedical research in our lifetime."

Sir Paul Nurse, Cancer Research UK

Your research papers will be:

- available free of charge to the entire biomedical community

- peer reviewed and published immediately upon acceptance

- cited in PubMed and archived on PubMed Central

- yours - you keep the copyright

Submit your manuscript here:

http://www.biomedcentral.com/info/publishing_adv.asp 